\title{
Genetic divergence and the mating system in the endangered and geographically restricted species, Lambertia orbifolia Gardner (Proteaceae)
}

\author{
DAVID J. COATES* \& VICKI L. HAMLEY \\ CALMScience, Western Australian Herbarium, Department of Conservation and Land Management, \\ Locked Bag 104, Bentley Delivery Centre, Western Australia 6983
}

\begin{abstract}
Population genetic structure and the mating system were investigated in the endangered plant Lambertia orbifolia. This species is geographically restricted with two disjunct groups of populations. Twelve out of 19 allozyme loci were polymorphic and four were suitable for mating system studies. Levels of genetic variation within populations were comparable to other long-lived woody shrub endemics. Genetic divergence between population groups was very high $(D=0.252)$ and the $F_{\mathrm{ST}}$ over all populations was 0.441 . Gene flow estimates within population groups were low even though the maximum geographical distance between any pair of populations is $15 \mathrm{~km}$ and could be attributed to the localized movement of bird pollinators. Mating system studies on four populations showed consistently low levels of outcrossing, compared with other Proteaceae. Correlations of outcrossed paternity were moderately high and all were significantly greater than zero. Values ranged from $r_{\mathrm{p}}=0.33$, in the two largest and very dense populations, to the highest value of $r_{\mathrm{p}}=0.54$ in a smaller low-density population. The current population genetic structure in L. orbifolia is probably the result of local extinction of intervening populations because of Pleistocene climatic change and increased aridity, and extended isolation of the two remnants. It is proposed that the phylogenetically distinct Narrikup population group be recognized as a separate conservation unit and be given high priority for conservation action.
\end{abstract}

Keywords: conservation units, endangered species, gene flow, genetic structure, habitat fragmentation, mating system.

\section{Introduction}

Naturally fragmented and disjunct population systems are a feature of the rich and diverse flora in south-west Australia. A significant proportion of the plant species is likely to be relictual and probably had wider, more continuous distributions during favourable climatic regimes up to the early Pleistocene. Increased aridity and climatic instability during the Pleistocene are considered to be major factors in the localized extinction and fragmentation of many plant species in this region (Hopper et al., 1996).

The level of geographical separation between population groups within these fragmented species suggests that recent gene flow, either by long-distance seed dispersal or pollen movement, has been limited or

*Correspondence. E-mail: davide@calm.wa.gov.au absent for a long period. Reduction or absence of gene flow, and fluctuations in population size caused by climatic instability, are likely to lead to significant interpopulation divergence. Studies to date on rare and geographically restricted species from south-west Australia support this view. Significant genetic divergence among populations associated with clear geographical separation is a feature of a range of species in a number of flowering plant families such as Mimosaceae (Coates, 1988), Myrtaceae (Moran \& Hopper, 1983, 1987; Sampson et al., 1988), Proteaceae (Coates \& Sokolowski, 1992) and Stylidiaceae (Coates, 1992).

A major confounding factor in assessing the evolutionary patterns observed in the south-west flora are the broad-scale effects of recent widespread land clearing over the last 150 years and the associated extensive habitat fragmentation. These events also have very significant implications for the conservation of this flora. Plant species in south-west Australia are now affected by 
rapid and recent habitat fragmentation superimposed upon a system of historically fragmented and isolated populations (see Hopper et al., 1996).

The genetic consequences of recent habitat fragmentation generally relate to the effects of reduced population size and increased geographical isolation among populations (Barrett \& Kohn, 1991; Young et al., 1997). In species with a continuous metapopulation structure, fragmentation is predicted to lead to a loss of genetic variation and increased divergence among populations. These effects result from increased drift, increased inbreeding, reduced gene flow between populations and local population extinction (Young et al., 1997). Limited studies to date support the prediction that habitat fragmentation and associated reduction in remnant size result in loss of genetic variation (see Prober \& Brown, 1994). The population genetic consequences of recent habitat fragmentation on already fragmented population systems are likely to be similar, although in those species with historically small isolated populations, loss of genetic variation and increased inbreeding may be more severe. Importantly, Young et al. (1997) point out that the effects of fragmentation have only been studied in a few plant species covering a limited range of ecological, reproductive and demographic traits and more studies are needed before more specific generalizations can be developed.

Population fragmentation, whether historical or resulting from recent habitat disturbance, might also be expected to affect the mating system, particularly in small isolated populations (Sampson et al., 1996; Young et al., 1997). There is only limited evidence to date to indicate a relationship between increased inbreeding and fragmentation (Young et al., 1997). However, Sampson et al. (1996) have shown that, in a number of species where fragmentation is also associated with habitat disturbance, lower levels of outcrossing are a feature of highly disturbed populations. In these cases habitat disturbance was linked to loss of pollinators, change in pollinator behaviour and the introduction of new pollinators.

Lambertia orbifolia is an endangered large woody shrub known from only seven populations that have a significant disjunct distribution. Like many Proteaceae, flowers are protandrous and geitogamous pollination is likely to be common. It is bird-pollinated with bird movement relatively restricted within populations (Whitaker \& Collins, 1997). Recent habitat fragmentation has affected all populations of $L$. orbifolia both in terms of reduction in size and increased isolation. The current population structure could be caused by recent fragmentation of a more continuous system of populations but appears more likely to be the result of historical fragmentation associated with Pleistocene climate change.

The aim of this study was to investigate the population genetic structure and the mating system in relation to both historical patterns and recent effects of fragmentation.

\section{Materials and methods}

\section{Distribution, population sampling and site descriptions}

Lambertia orbifolia has a disjunct distribution, with populations occurring in two discrete areas approximately $200 \mathrm{~km}$ apart in south-west Western Australia (Fig. 1). Five populations are located in the Scott River Plains area east of Augusta and two populations are found $30 \mathrm{~km}$ north of Albany near Narrikup.

The five Scott River Plains populations are found on sandy soils over ironstones in winter-wet depressions and seasonally inundated wetlands. These areas
Fig. 1 Distribution and number of mature plants for all populations of Lambertia orbifolia.

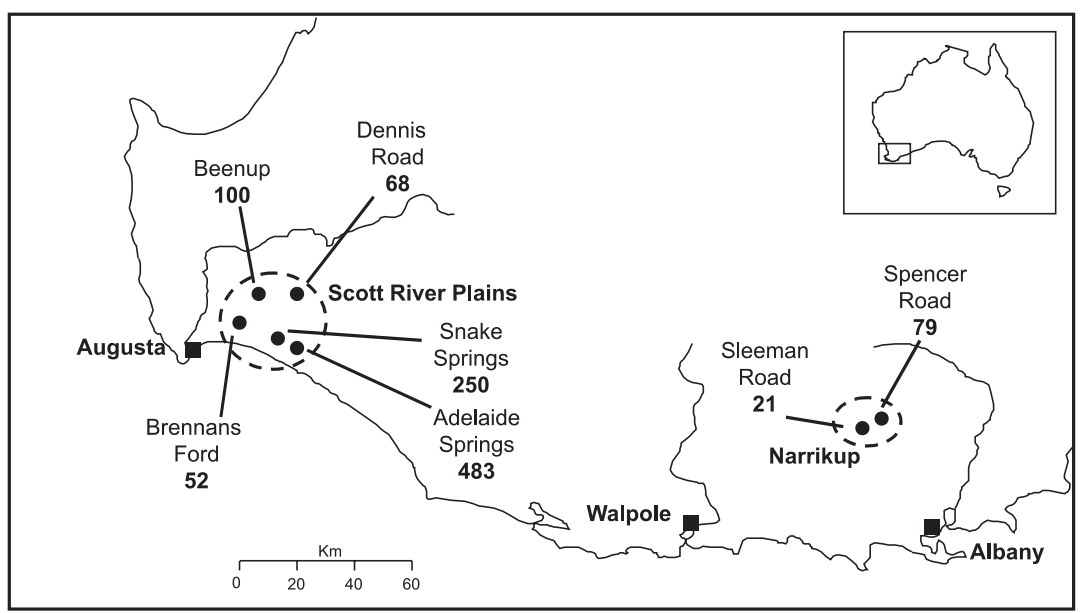

(c) The Genetical Society of Great Britain, Heredity, 83, 418-427. 
comprise floristically diverse low woodland and scrub heath communities. The coastal sites at Adelaide Springs and Snake Springs comprise relatively large, dense populations of large shrubs to small trees up to $5 \mathrm{~m}$ in height. In the three smaller inland populations at Brennans Ford, Dennis Rd and Beenup, L. orbifolia occurs as clumps of several plants or as dispersed individuals. The two smallest populations at Narrikup are found on sandy loams over laterite in open, low forest with a species composition different from that found in the Scott River Plains area. Plant density in both Narrikup populations is similar to the large coastal Scott River Plains populations. Population sizes are shown in Fig. 1.

The level of habitat disturbance resulting from land clearing differs markedly between populations. In the populations at Adelaide Springs, Snake Springs and Brennans Ford, vegetation disturbance is limited to the population periphery and adjacent areas. At Beenup both past grazing and disease caused by the root rot fungus Phytophthora cinnamomi has resulted in some habitat degradation, particularly in adjacent areas. Road verge populations at Dennis $\mathrm{Rd}$, Spencer $\mathrm{Rd}$ and Sleeman $\mathrm{Rd}$ are characterized by significant habitat degradation associated with weed invasion and loss of the associated flora. The Spencer Rd population is also infected with Phytophthora root rot and a canker fungus, and has shown significant decline from 139 plants at the time of sampling in 1994-95 to 79 plants in 1998.

Seed was collected from at least 10 plants per population in conjunction with larger seed collections for ex situ germ plasm storage. Follicles contain one to two seeds each and were collected from inflorescences scattered over the plant. Follicles become ripe within 8-9 months (Sage, 1994) and then dehisce. Seed samples therefore generally represent the products of fertilization for the year of sampling.

\section{Isozyme electrophoresis}

Up to 25 seeds per plant were germinated on moistened filter paper. The number of seeds used per population was dependent upon sample size requirements for mating system studies. Seedlings with recently emerged radicals, minus the bulk of the large endosperm, provided the best material. Preparation of this material and the isozyme methods, using the Helena Laboratory cellulose acetate plate electrophoresis system, have been described previously by Coates (1988).

Eleven enzyme systems were assayed: aspartate aminotransferase (AAT, EC 2.6.1.1), alcohol dehydrogenase (ADH, EC 1.1.1.1), esterase (EST, EC 3.1.1.-), glucose phosphate isomerase (GPI, EC 5.3.1.9), glutamate dehydrogenase (GDH, EC 1.4.1.2), leucine aminopepti- dase (LAP, EC 3.4.11.1), malate dehydrogenase (MDH, EC 1.1.1.37), malic enzyme (ME, EC 1.1.1.40), menadione reductase (MDR, EC 1.6.99.22), phosphoglucomutase (PGM, EC 5.4.2.2) and shikimate dehydrogenase (SDH, EC 1.1.1.25). Nineteen zones of activity were scored and each zone was assumed to represent a single locus. Sixteen polymorphic loci were detected. Their genetic interpretation was based on segregation patterns of progeny arrays from open-pollinated families from the four populations used in mating system studies. The locus $M e-1$ was only resolved in the Narrikup populations and therefore not used in the population genetic studies but was used in the mating system analysis of the Spencer Rd population.

\section{Genetic variation within and among populations, and gene flow}

The average number of alleles per locus $(A)$, percentage polymorphic loci $(P)$, observed heterozygosity $\left(H_{\mathrm{o}}\right)$ and gene diversity (expected panmictic heterozygosity) $\left(H_{\mathrm{e}}\right)$ were estimated at the population level. Differences in genetic variation between the Scott River Plains and Narrikup populations were determined using a nested ANOVA. Fixation indices $\left(F_{\text {IS }}\right)$ (Wright, 1978) were estimated to examine population deviation from random mating. The goodness-of-fit of observed genotype frequencies at each locus to those expected under Hardy-Weinberg equilibrium was tested by $G$-test.

Interpopulation divergence was estimated using Nei (1978) unbiased genetic distance $(D)$ and $F_{\mathrm{ST}}$ (Wright, 1978). Nei (1978) unbiased genetic distance $(D)$ was calculated between all populations and then the mean $D$ determined for populations within the Scott River Plains area, the Narrikup area and for all populations. It was also used to construct a UPGMA phenogram. Separate estimates of $F_{\mathrm{ST}}$ were made for the Scott River Plains populations, Narrikup populations and for all populations. The indirect estimate of gene flow $(\mathrm{Nm})$ was calculated over all populations and within the two population groups based on the relationship $F_{\mathrm{ST}}=$ $1 /[4 N m+1]$ (Wright, 1978).

Single-locus diversity measures, $F_{\mathrm{IS}}$, Nei's $D$, HardyWeinberg test, $F_{\mathrm{ST}}, N m$ and the UPGMA phenogram were determined using the computer program POPGENE (Yeh $\&$ Boyle, 1997). Phylogenetic relationships among populations were also investigated by the restriction maximum likelihood method using gene frequency data. Multiple datasets (500) were generated by bootstrapping, a phylogeny determined for each dataset by the restriction maximum likelihood method and a consensus tree generated. The computer programs SEGBOOT, CONTML and CONSENSE in PHYLIP 3.5 (Felsenstein, 1995) were used for this analysis. 


\section{Mating system analysis}

Four loci were used to estimate mating system parameters in four populations: Adelaide Springs, Snake Springs and Beenup from the Scott River Plains area and Spencer Rd from the Narrikup area. Three loci (Est-1, Est-3 and $S d h-2$ ) were used to estimate mating system parameters in the Scott River Plains area whereas Est-1, Est-3 and $M e-1$ were used to estimate mating system parameters in the Narrikup population. Estimates were based on 13-18 families per population with a mean of 11.5-20.5 progeny per family.

Mating system estimates based on different loci may be correlated if those loci show linkage disequilibrium. To test for associations between loci, Burrows's composite measure of linkage disequilibria $\left(\Delta_{\mathrm{AB}}\right)$ was calculated for all possible pairs of loci within populations with $\chi^{2}$ tests for significance according to Weir (1990), using the computer package POPGENE (Yeh \& Boyle, 1997).

Maximum likelihood estimates of single-locus $\left(t_{\mathrm{s}}\right)$ and multilocus $\left(t_{\mathrm{m}}\right)$ outcrossing rates (Ritland \& Jain, 1981) were based on the mixed-mating model of Brown \& Allard (1970) with maternal genotypes inferred from progeny arrays. Correlation of outcrossed paternity $\left(r_{\mathrm{p}}\right)$ was estimated according to the sibling-pair model (Ritland, 1989). The inbreeding coefficient of maternal parents $\left(F_{\mathrm{m}}\right)$ was also calculated. All mating system parameters were estimated using the computer program MLTR version 0.9 (available from K. Ritland). Standard errors for the population estimates of $t_{\mathrm{s}}, t_{\mathrm{m}}, r_{\mathrm{p}}, F$ and $t_{\mathrm{m}}-t_{\mathrm{s}}$ were based on 500 bootstraps with resampling among maternal plants (see Sun \& Ritland, 1998).

\section{Results}

\section{Genetic variation within populations}

Three loci (Aat-2, Mdh-1 and Pgi-1) were monomorphic across all populations. Five loci (Pgm-1, Pgm-2, Aat-1, Est-2 and Mnr-3) were monomorphic in six out of seven populations, with a rare allele found at each locus in the remaining population. There was also a fixed difference between the two population groups, Scott River Plains and Narrikup, at the Mnr-2 locus. The other 10 loci were polymorphic in most populations. Six loci $(A d h-1$, Est-1, Gdh-1, Lap-1, Sdh-1 and $S d h-2)$ had relatively uniform allele frequencies across all populations. Three loci (Est-3, Mnr-1 and Mdh-1) showed significant allele frequency differences between the Narrikup and Scott River Plains populations (Fig. 2), whereas at the Aat-3 locus, a unique allele was found at a frequency of 0.20 in the Spencer Rd population.

The population means for allelic richness $(A)$, percentage polymorphic loci $(P)$, gene diversity $\left(H_{\mathrm{e}}\right)$ and heterozygosity $\left(H_{\mathrm{o}}\right)$ are presented in Table 1 . Polymorphism, allelic richness, gene diversity and heterozygosity were all moderately lower in the Scott River Plains populations than in the Narrikup populations, although the differences were not significant. The mean for all population estimates, $P=41.1, A=1.5, H_{\mathrm{e}}=0.11$, $H_{\mathrm{o}}=0.06$, is relatively low for animal-pollinated outcrossing species (see Hamrick \& Godt, 1989).

Population fixation indices $\left(F_{\mathrm{IS}}\right)$ were positive in all populations and significantly greater than zero in the Snake Springs, Brennans Ford, Dennis Rd and Spencer $\mathrm{Rd}$ populations. These results indicate a general excess of homozygotes in the seed progeny.
Fig. 2 Allele frequencies for the loci $M d h-1$, Est-3 and Mnr-1 in all populations of Lambertia orbifolia.

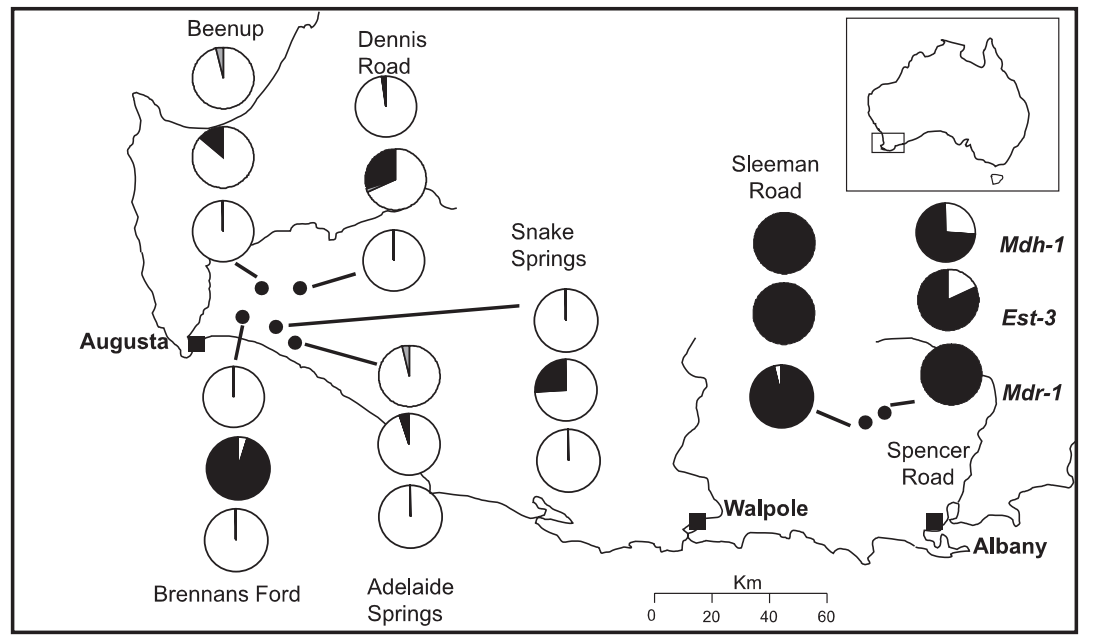

(C) The Genetical Society of Great Britain, Heredity, 83, 418-427. 
Table 1 Population sizes, genetic diversity statistics $\dagger$, fixation indices $\left(F_{\mathrm{IS}}\right)$ for all populations of Lambertia orbifolia

\begin{tabular}{lcccccc}
\hline Population & $\begin{array}{c}\text { Number of } \\
\text { mature plants }\end{array}$ & $A(\mathrm{SE})$ & $P(\mathrm{SE})$ & $H_{\mathrm{e}}(\mathrm{SE})$ & $H_{\mathrm{o}}(\mathrm{SE})$ & $F_{\mathrm{IS}}(\mathrm{SE})$ \\
\hline $\begin{array}{l}\text { Scott River Plains } \\
\text { Adelaide Springs }\end{array}$ & 483 & $1.4(0.1)$ & 36.8 & $0.08(0.04)$ & $0.06(0.03)$ & $0.24(0.15)$ \\
Snake Springs & 250 & $1.4(0.1)$ & 36.8 & $0.10(0.04)$ & $0.05(0.03)$ & $0.31(0.12)$ \\
Brennans Ford & 52 & $1.4(0.1)$ & 31.6 & $0.08(0.04)$ & $0.04(0.02)$ & $0.29(0.14)$ \\
Beenup & $\approx 100$ & $1.7(0.2)$ & 52.6 & $0.11(0.04)$ & $0.07(0.03)$ & $0.26(0.16)$ \\
Dennis Rd & 68 & $1.4(0.1)$ & 35.0 & $0.13(0.05)$ & $0.06(0.02)$ & $0.47(0.11)$ \\
Mean & & $1.5(0.1)$ & $38.5(3.6)$ & $0.10(0.02)$ & $0.06(0.01)$ & $0.31(0.03)$ \\
Narrikup & & & & & & \\
Spencer Rd & 79 & $1.6(0.2)$ & 47.4 & $0.16(0.05)$ & $0.08(0.03)$ & $0.37(0.09)$ \\
Sleeman Rd & 21 & $1.6(0.1)$ & 47.4 & $0.10(0.04)$ & $0.07(0.03)$ & $0.29(0.15)$ \\
Mean & & $1.6(0.1)$ & 47.4 & $0.13(0.03)$ & $0.08(0.01)$ & $0.33(0.04)$ \\
Mean all populations & & $1.5(0.05)$ & $41.1(3.0)$ & $0.11(0.01)$ & $0.06(0.01)$ & $0.32(0.03)$ \\
\hline
\end{tabular}

$\dagger A$, mean number of alleles per locus; $P$, percentage of polymorphic loci; $H_{\mathrm{e}}$, gene diversity; $H_{\mathrm{o}}$, observed heterozygosity.

\section{Population differentiation}

Divergence between the Scott River Plains and Narrikup populations, measured by $F_{\mathrm{ST}}$ and Nei's unbiased genetic distance $(D)$, was extremely high (Table 2). The average $F_{\mathrm{ST}}$ among all populations was 0.441 and the mean $D$ was 0.142 . The genetic distance between the Narrikup and Scott River Plains populations was $D=0.252$. The level of divergence, measured by $D$, among populations within both areas was low. However, the $F_{\mathrm{ST}}$ values were relatively high suggesting that significant genetic differentiation is present even among geographically close populations.

Gene flow estimates within population groups were low even though the maximum geographical distance between any pair of populations is $15 \mathrm{~km}$ in the Scott River Plains area. The overall estimated level of gene flow among all populations was extremely low $(\mathrm{Nm}=0.317)$ and is indicative of long-term historical isolation.

The analysis of phylogenetic relationships among all populations, based on UPGMA or maximum likelihood methods, gave identical tree topologies (Fig. 3). The

Table 2 Nei's unbiased genetic distance $(D), F_{\mathrm{ST}}$ and gene flow estimates $(\mathrm{Nm})$ within and between the two population groups in Lambertia orbifolia

\begin{tabular}{lccc}
\hline $\begin{array}{l}\text { Population } \\
\text { group }\end{array}$ & \multicolumn{1}{c}{$D(\mathrm{SE})$} & $F_{\mathrm{ST}}(\mathrm{SE})$ & $\mathrm{Nm}$ \\
\hline Scott River Plains & $0.042(0.009)$ & 0.238 & 0.801 \\
Narrikup & 0.049 & 0.143 & 1.494 \\
All & $0.142(0.024)$ & 0.441 & 0.317 \\
Narrikup vs. & 0.252 & & \\
$\quad$ Scott River Plains & & & \\
\hline
\end{tabular}

Narrikup and Scott River Plains populations were clearly separate lineages. Coastal populations in the Scott River Plains area (Adelaide Springs, Snake Springs) grouped together and were separated from the more inland populations at Beenup and Dennis Rd.

\section{Mating system}

The estimates of Burrows's composite linkage disequilibrium $\Delta_{\mathrm{AB}}$ among the four loci (Est-1, Est-3, Sdh-2 and $M e-1)$ indicated no significant disequilibrium in any of the populations. Therefore all four loci were used in estimating mating system parameters.

Multilocus and mean single-locus estimates of outcrossing rates for four populations (Adelaide Springs, Snake Springs, Beenup and Spencer Rd) are given in Table 3. All four populations had outcrossing rates significantly less than one. The outcrossing rate in the small Narrikup population (Spencer $\mathrm{Rd}, t_{\mathrm{m}}=0.41$ ) was significantly lower than the mean outcrossing rate for the larger Scott River Plains populations $\left(t_{\mathrm{m}}=0.61\right)$. There was no relationship between population size and outcrossing rate within the Scott River Plains populations. Although there was no significant difference between the mean single-locus and multilocus outcrossing estimates the single-locus estimates were moderately lower in all populations. Low levels of biparental inbreeding may be contributing to this trend.

The correlations of outcrossed paternity $r_{\mathrm{p}}$ (the probability that sibs shared the same father) were moderately high and all were significantly greater than zero (Table 3). Values ranged from $r_{\mathrm{p}}=0.33$, in the two largest and very dense populations at Adelaide Springs and Snake Springs, to the highest value of $r_{\mathrm{p}}=0.54$ in the smaller, low-density population at 
(a)
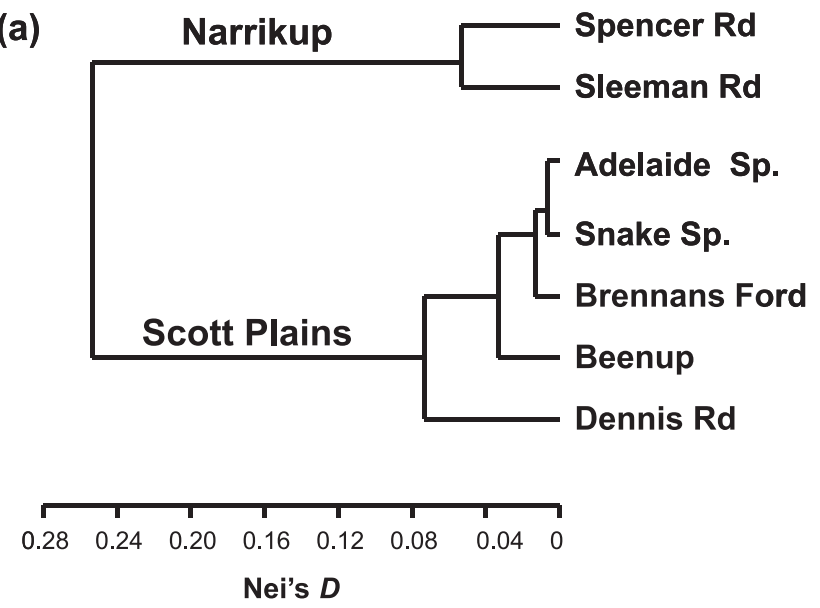

(b)

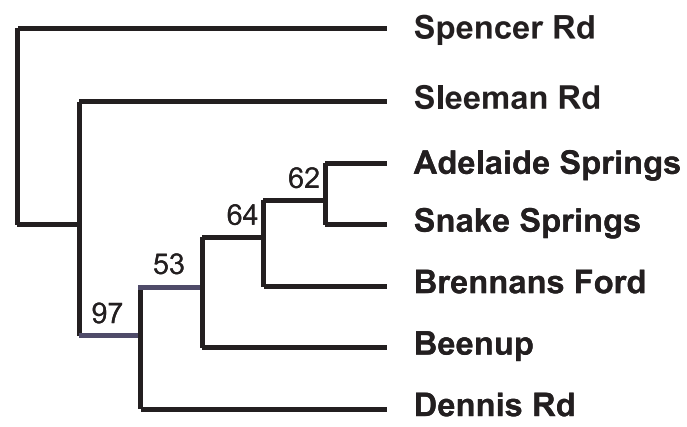

Fig. 3 (a) UPGMA clustering based on Nei's unbiased genetic distance. (b) Restriction Maximum Likelihood tree based on allele frequency. Bootstrap percentages are shown for each branch.
Beenup. The smallest relatively high-density road verge population at Spencer Rd had a correlated paternity $\left(r_{\mathrm{p}}=0.35\right)$ similar to the two largest populations. The 'paternal mating pool', the estimated number of sires per plant, was low in all populations, ranging from three to four plants in the larger more dense populations to one to two plants in the Beenup population. These low overall values probably reflect the size of the plants and the limited movement of the bird pollinators between plants. These data indicate that the size of the paternal mating pool is associated with population density.

The average fixation index for the maternal plants $\left(F_{\mathrm{m}}=0.09\right.$, Table 3$)$ is significantly lower than the average population estimate based on seed progeny $\left(F_{\text {IS }}=0.32\right.$, Table 1$)$. This indicates selection favouring heterozygous individuals as plants mature from seedling to adult.

\section{Discussion}

\section{Genetic structure and population divergence}

The high levels of genetic divergence and population phylogenetic analyses indicate that the two disjunct population groups at Scott River Plains and Narrikup have been historically isolated for an extended period of time. There is little evidence to suggest, from these data, that the current distribution of populations is the result of recent habitat fragmentation. In addition, large areas of undisturbed vegetation still occur between the two population groups and, despite extensive surveys, no further populations have been located. The possibility

Table 3 Population size and mating system estimates $\uparrow$ for four populations of Lambertia orbifolia: (d) indicates dense populations where individual plants were usually separated by $1-3 \mathrm{~m}$, (s) indicates plants were sparsely distributed, usually separated by $3 \mathrm{~m}$ or more

\begin{tabular}{lccccccc}
\hline & $\begin{array}{c}\text { Number of } \\
\text { mature plants }\end{array}$ & $F_{\mathrm{m}}(\mathrm{SE})$ & $t_{\mathrm{m}}(\mathrm{SE})$ & $t_{\mathrm{s}}(\mathrm{SE})$ & $t_{\mathrm{m}}-t_{\mathrm{s}}(\mathrm{SE})$ & $r_{\mathrm{p}}(\mathrm{SE})$ & $\begin{array}{c}\text { Paternal } \\
\text { neighbourhood } \\
\text { size } \\
\left(1 / r_{\mathrm{p}}\right)\end{array}$ \\
\hline $\begin{array}{l}\text { Population } \\
\begin{array}{l}\text { Scott River Plains } \\
\text { Adelaide }\end{array}\end{array}$ & 483 & $0.28(0.16)$ & $0.53(0.08)^{*}$ & $0.46(0.08)^{*}$ & $0.07(0.03)$ & $0.33(0.06)^{*}$ & $3-4$ \\
$\begin{array}{l}\text { Springs (d) } \\
\begin{array}{l}\text { Snake } \\
\quad \text { Springs (d) }\end{array}\end{array}$ & 250 & $0.01(0.03)$ & $0.72(0.10)^{*}$ & $0.63(0.09)^{*}$ & $0.09(0.04)$ & $0.33(0.08)^{*}$ & $3-4$ \\
$\begin{array}{l}\text { Beenup (s) } \\
\begin{array}{l}\text { Mean } \\
\text { Narrikup }\end{array}\end{array}$ & 100 & $0.04(0.08)$ & $0.57(0.11)^{*}$ & $0.55(0.11)^{*}$ & $0.02(0.02)$ & $0.54(0.18)^{*}$ & $1-2$ \\
$\begin{array}{l}\text { Spencer } \\
\text { Road (d) }\end{array}$ & 56 & $0.11(0.09)$ & $0.61(0.06)^{*}$ & $0.55(0.05)^{*}$ & $0.06(0.02)$ & $0.40(0.07)^{*}$ & \\
\hline
\end{tabular}

$\dagger F_{\mathrm{m}}$, inbreeding coefficient of maternal parents; $t_{\mathrm{m}}$, multilocus outcrossing rate; $t_{\mathrm{s}}$, single-locus outcrossing rate; $r_{\mathrm{p}}$, correlation of outcrossed paternity.

*Significantly less than 1 for $t_{\mathrm{m}}$ and $t_{\mathrm{s}}$, and significantly greater than zero for $r_{\mathrm{p}}(P<0.05)$.

(C) The Genetical Society of Great Britain, Heredity, 83, 418-427. 
that the two road verge populations are the result of recent introductions from the Scott River Plains area can also be discounted, given the level of the genetic differences between the population groups.

The long-term effects of Pleistocene climatic change and increased aridity on the south-west Australian flora suggest that the current population genetic structure in L. orbifolia is the result of local extinction of intervening populations, and extended isolation of the two remnants. Local extinction and range contraction, resulting from climate change, are particularly evident in a number of large forest Eucalyptus species that occur in areas between the two L. orbifolia population groups (Wardell-Johnson \& Coates, 1996).

All populations of $L$. orbifolia appear to have been affected to some extent by recent habitat fragmentation. This has resulted in a reduction and ongoing decline in population size, particularly in the road verge populations at Dennis Rd, Spencer Rd and Sleeman Rd. From theoretical predictions and a number of empirical studies the smaller L. orbifolia populations might be expected to show reduced levels of polymorphism and allelic richness (Barrett \& Kohn, 1991; Young et al., 1997). However, comparisons between populations showed no association of decreased population size with a reduction in any measure of genetic variation (Table 2). The smallest isolated populations at Narrikup had marginally higher levels of allelic richness and polymorphism than the larger Scott River Plains populations. It is possible that the initial reduction in population size has not been great enough to cause a detectable loss in genetic variation. The Narrikup populations may also have been much larger until relatively recently. Land clearing has been more widespread and ongoing adjacent to the Narrikup populations than in the Scott River Plains area. It is also likely that insufficient time has elapsed for drift and inbreeding, because of small population size, to have any major effect, particularly as the life cycle of these plants is probably 25 years or longer.

The level of genetic diversity observed in L. orbifolia $\left(H_{\mathrm{e}}=0.11\right)$, although low when compared with other long-lived, woody angiosperms (Hamrick et al., 1992), is similar to or moderately higher than other members of the Proteaceae. Allozyme studies on species from a number of genera within the Proteaceae such as Banksia (Coates \& Sokolowski, 1992; Carthew, 1993; Sampson et al., 1994), Grevillea (Ayre et al., 1994) and Persoonia (Krauss, 1997) have revealed relatively low levels of genetic variability within populations. Krauss (1997) suggested that the low levels of genetic variation in Persoonia mollis, which is killed and regenerates from seed after fire, resulted from localized extinction and founder events caused by frequent fires in a fire-prone habitat. He also proposed that other Proteaceae and non-Proteaceae with similar life histories may be affected in the same way. Although Krauss (1997) points out that further studies are required, limited investigations to date do not support his proposal; for example, studies on other genera with analogous life histories that occur in fire-prone habitats, such as Acacia (Mimosaceae), Daviesia (Papilionaceae) and Eremaea (Myrtaceae), indicate relatively high levels of genetic diversity (Coates, 1988; Coates \& Hnatiuk, 1989; Young \& Brown, 1998).

The evolutionary history of the populations provides the most probable explanation for the low levels of genetic variation found in L. orbifolia. Fluctuations in population size and local extinctions, associated with climatic instability over a relatively long period of time, are all likely to be contributing factors. Comparisons with other long-lived, woody shrub endemics also show that the levels of genetic diversity observed in L. orbifolia are not unusually low for a geographically restricted species (Hamrick et al., 1992; Young \& Brown, 1998).

\section{Mating system}

Analysis of the mating system of L. orbifolia showed significant levels of selfing in the four populations studied (Table 3). The difference between multilocus and mean single-locus estimates of outcrossing rate in the high-density Adelaide Springs and Snake Springs populations suggest that at least some biparental inbreeding may be operating at those two sites. This finding is not unexpected given the size and density of those populations. In the other populations inbreeding can be almost entirely attributed to self-fertilization. Bird pollinator behaviour observations indicate that most bird movements are less than $5 \mathrm{~m}$ which would involve many intraplant flower visits covering only two or three mature plants (Whitaker \& Collins, 1997). This behaviour would ensure significant levels of selfing, and some biparental inbreeding in dense populations with limited seed dispersal.

Mating systems have now been investigated in a number of trees and shrubs of the Australian Proteaceae. Flowering is generally seasonal and often involves mass flowering of many large inflorescences over a relatively restricted period of time. Most of these studies have focused on the genus Banksia. With the exception of Banksia brownii (Sampson et al., 1994), high outcrossing rates were typical of most populations (see Carthew et al., 1988; Coates \& Sokolowski, 1992). Very high outcrossing rates were observed in another member of the family, Persoonia mollis (Krauss, 1994). In contrast, consistently low levels of outcrossing were 
found in all four populations of L. orbifolia. One possible explanation is that the low overall outcrossing rates result from the flowering phenology of this species. Lambertia orbifolia flowers throughout the year with flowering peaks in January to February and May to July. Rather than limited mass flowering associated with high pollinator activity, inflorescences are more sparsely distributed over the plants and pollinator activity is likely to be lower, more territorial, but consistent throughout the year.

Interpopulation comparisons of mating system parameters revealed a notably lower level of outcrossing rate in the Spencer Rd population compared with the Scott River Plains populations (Table 3). This was also associated with significantly lower levels of fruit-set (Sage, 1994). Unlike the other three populations, this narrow road-side population has high levels of habitat disturbance. The associated vegetation is degraded in terms of loss of a significant number of plant species, weed invasion and disease caused by the root rot fungus Phytophthora cinnamomi. Reduced levels of outcrossing as a result of habitat disturbance have been observed in a number of species, including other members of the Proteaceae such as Banksia cuneata and B. tricuspis (see Sampson et al., 1996) and Grevillea barklyana (Ayre et al., 1994). This was attributed primarily to loss of pollinators or change in pollinator behaviour, concomitant with the loss of many associated plant species important for the maintenance of pollinator populations.

Correlations of outcrossed paternity were high and significantly greater than zero in the four populations studied. Each maternal plant appears to be pollinated by a small number of fathers. This interpretation is consistent with pollinator observations that also indicate the majority of fathers are probably near-neighbours. The small number of potential fathers is clearly reflected in the estimates of the average paternal mating pool (see Sun \& Ritland, 1998). Even in the largest population at Adelaide Springs the estimated paternal mating pool is no greater than four.

There was no obvious relationship between population size and correlated paternity. However, a higher correlated paternity was found in the low-density Beenup population. A number of studies have shown that population density will influence pollinator movements and thus mating system parameters (see Karron et al., 1995). Young \& Brown (1998) found that in Daviesia mimosoides both population size and density were negatively associated with correlated paternity. They proposed that reduced density may increase intraplant pollinator movement and increase the likelihood of a pair of flowers on the same plant receiving the same outcrossed pollen. Estimates of the paternal mating pool indicate that most of the outcrossed pollen in the low-density Beenup population comes from only one or two fathers.

\section{Conclusions and implications for conservation}

Lambertia orbifolia appears to consist of two historically isolated and independently evolving population remnants. It seems likely that these population groups have been isolated and stable for a long period of time. Demographic and genetic data support the view that the Scott Plains and Narrikup populations should be recognized as distinct units for conservation and that they can probably be defined as Evolutionary Significant Units (ESUs) (see Moritz, 1994; Vogler \& Desalle, 1994).

The effects of recent habitat fragmentation on the historically disjunct and fragmented population system found in L. orbifolia were less than predicted from theoretical and other empirical studies. The smaller Narrikup population at Spencer Rd did have a reduced outcrossing rate which could be attributed both to the small size of the population and increased habitat disturbance. However, there was no evidence to suggest that the smaller populations had less genetic variability. As discussed above, this may be because the decrease in population size was not great enough to affect the level of genetic variation. Also, there may have been insufficient time since recent fragmentation for genetic drift and increased isolation to be effective in reducing genetic variation. Another, more speculative possibility, is that these populations have always been relatively small and isolated, with the capacity to maintain high levels of genetic variability in association with extensive balanced polymorphisms. Such a system would probably also result in a substantial genetic load (see James, 1996).

Lambertia orbifolia has an IUCN ranking of endangered. However, given the large number of critically endangered plants in Western Australia it has a relatively low priority for conservation and recovery actions. Small population size, increased inbreeding and threats posed by disease and habitat degradation indicate that the phylogenetically distinct Narrikup populations are critically endangered. It is proposed that the two population groups be considered separate conservation units and the Narrikup populations be given a high priority for conservation action.

\section{Acknowledgements}

We thank Anne Cochrane for seed collections, Peta Whitaker for technical assistance, Matt Williams for assistance in data analysis and Margaret Byrne for reviewing the manuscript. This research was supported by the Commonwealth Threatened Species and 
Communities Section, Biodiversity Group, Environment Australia.

\section{References}

AYRE, D. J., WHELAN, R. J. AND REID, A. 1994. Unexpectedly high levels of selfing in the Australian shrub Grevillea barklyana (Proteaceae). Heredity, 72, 168-174.

BARRETT, S. C. H. AND KOHN, J. R. 1991. Genetic and evolutionary consequences of small population size in plants: implications for conservation. In: Falk, D. A. and Holsinger, K. E. (eds) Genetics and Conservation of Rare Plants, pp. 3-30. Oxford University Press, New York.

BROWN, A. H. D. AND ALlARD, R. W. 1970. Estimation of the mating system in open-pollinated maize populations using isozyme polymorphisms. Genetics, 66, 133-145.

CARTHEw, S. M. 1993. Population genetic structure of Banksia spinulosa. Heredity, 70, 566-573.

CARTHEW, S. M., AYRE, D. J. AND WHELAN, R. J. 1988. High levels of outcrossing in populations of Banksia spinulosa $\mathrm{R}$. Br. and Banksia paludosa Smith. Aust.J. Bot., 36, 217-223.

COATES, D. J. 1988. Genetic diversity and population genetic structure in rare Chittering Grass Wattle, Acacia anoma Court. Aust. J. Bot., 36, 273-286.

COATES, D. J. 1992. Genetic consequences of a bottleneck and spatial genetics structure in the triggerplant Stylidium coroniforme (Stylidiaceae). Heredity, 69, 512-520.

COATES, D. J. AND HNATIUK, R. J. 1989. Systematic and evolutionary inferences from isozyme studies in the genus Eremaea (Myrtaceae). Aust. Syst. Bot., 3, 59-74.

COATES, D. J. AND SOKOLOWSKI, R. E. 1992. The mating system and patterns of genetic variation in Banksia cuneata A. S. George (Proteaceae). Heredity, 69, 11-20.

FELSENSTEIN, J. 1995. PHYLIP (Phylogeny Inference Package), Version 3.5c. Department of Genetics, The University of Washington, Seattle.

HAMRICK, J. L. AND GODT, M. J. W. 1989. Allozyme diversity in plant species. In: Brown, A. H. D., Clegg, M. T., Kahler, A. L. and Weir, B. S. (eds) Plant Population Genetics, Breeding, and Genetic Resources, pp. 43-63. Sinauer Associates, Sunderland, MA.

HAMRICK, J. L., GODT, M. J. W. AND SHERMAN-BROYLES, S. L. 1992. Factors influencing levels of genetic diversity in woody plant species. New Forests, 6, 95-124.

HOPPER, S. D., HARVEY, M. S., CHAPPILL, J. A., MAIN, A. R. AND MAIN, B. Y. 1996. The Western Australian biota as Gwondwanan heritage - a review. In: Hopper, S. D., Chappill, J. A., Harvey, M. S. and George, A. S. (eds) Gondwanan Heritage: Past, Present and Future of the Western Australian Biota, pp. 1-46. Surrey Beatty \& Sons, Chipping Norton.

JAMES, S. H. 1996. Seed abortion and the evolution of genetic systems in some Australian native plant groups. In: Hopper, S. D., Chappill, J. A., Harvey, M. S. and George, A. S. (eds) Gondwanan Heritage: Past, Present and Future of the Western Australian Biota, pp. 90-99. Surrey Beatty \& Sons, Chipping Norton.
KARRON, J. D., THUMSER, N. N., TUCKER, R. AND HESSENAUER, A. J. 1995. The influence of population density on outcrossing rates in Mimulus ringens. Heredity, 75, 175180.

KRAUSS, S. L. 1994. Restricted gene flow within the morphologically complex species Persoonia mollis (Proteaceae): contrasting evidence from the mating system and pollen dispersal. Heredity, 73, 142-154.

KRAUSS, S. L. 1997. Low genetic diversity in Persoonia mollis (Proteaceae), a fire-sensitive shrub occurring in a fire-prone habitat. Heredity, 78, 41-49.

MORAN, G. F. AND HOPPER, S. D. 1983. Genetic diversity and insular population structure of the rare granite rock species Eucalyptus caesia Benth. Aust. J. Bot., 31, 161-172.

MORAN, G. F. AND HOPPER, S. D. 1987. Conservation of the genetic resources of rare and widespread eucalypts in remnant vegetation. In: Saunders, D. A., Arnold, G. W., Burbidge, A. A. and Hopkins, A. J. M. (eds) Nature Conservation: The Role of Remnants of Native Vegetation, pp. 151-162. Surrey Beatty \& Sons, Chipping Norton.

MORITZ, C. 1994. Defining evolutionary significant units for conservation. Trends Ecol. Evol., 9, 373-375.

NEI, M. 1978. Estimation of average heterozygosity and genetic distance from a small number of individuals. Genetics, 89, 583-590.

PROBER, S. M. AND BROWN, A. H. D. 1994. Conservation of the grassy white box woodlands: Population genetics and fragmentation of Eucalyptus albens. Conserv. Biol., 8, $1003-1013$.

RITLAND, K. 1989. Correlated matings in the partial selfer, Mimulus guttatus. Evolution, 43, 848-859.

RITLAND, K. AND JAIN, S. K. 1981. A model for the estimation of outcrossing rate and gene frequencies using $\mathrm{n}$ independent loci. Heredity, 47, 35-52.

SAGE, L. 1994. The Conservation Requirements of the Rare Species Lambertia orbifolia. Honours Thesis. Curtin University of Technology, Perth.

SAMPSON, J. F., HOPPER, S. D. AND JAMES, S. H. 1988. Genetic diversity and the conservation of Eucalyptus crucis Maiden. Aust. J. Bot., 36, 447-460.

SAMPSON, J. F., COllins, B. G. AND COATES, D. J. 1994. Mixed mating in Banksia brownii Baxter ex R. Br. (Proteaceae). Aust. J. Bot., 42, 103-111.

SAMPSON, J. F., COATES, D. J. AND VAN LEEUWEN, S. J. 1996. Mating system variation in animal-pollinated rare and endangered plant populations in Western Australia. In: Hopper, S. D., Chappill, J. A., Harvey, M. S. and George, A. S. (eds) Gondwanan Heritage: Past, Present and Future of the Western Australian Biota, pp. 187-195. Surrey Beatty \& Sons, Chipping Norton.

SUN, M. AND RITLAND, K. 1998. Mating system of yellow starthistle (Centaurea solstitialis), a successful colonizer in North America. Heredity, 80, 225-232.

vogler, A. P. AND Desalle, R. 1994. Diagnosing units of conservation management. Conserv. Biol., 8, 354-363.

WARDELL-JOHNSON, G. AND COATES, D. J. 1996. Links to the past: local endemism in four species of forest eucalypts in southwestern Australia. In: Hopper, S. D., Chappill, J. A., Harvey, M. S. and George, A. S. (eds) Gondwanan Heritage: 
Past, Present and Future of the Western Australian Biota, pp. 137-154. Surrey Beatty \& Sons, Chipping Norton.

WEIR, B. S. 1990 Genetic Data Analysis. Sinauer Associates, Sunderland, MA.

WhitAKer, P. K. AND COllins, B. G. 1997. Pollen Vectors for the Rare Species Lambertia orbifolia. Report to the Department of Conservation and Land Management. School of Environmental Biology, Curtin University of Technology, Perth. Wright, s. 1978 Evolution and the Genetics of Populations, vol 4, Variability Within and Among Natural Populations. University of Chicago Press, Chicago.
YEH, F. C. AND BOYLE, T. J. B. 1997. POPGENE, Version 1.1. Department of Renewable Resources, University of Alberta, Edmonton, Alberta.

YOUNG, A. G. AND BROWN, A. H. D. 1998. Comparative analysis of the mating system of the rare woodland shrub Daviesia suaveolens and its common congener D. mimosoides. Heredity, 80, 374-381.

YOUNG, A. G., BOYLE, T. J. B. AND BROWN, A. H. D. 1997. The population genetic consequences of habitat fragmentation for plants. Trends Ecol. Evol., 11, 413-418. 